\title{
江戸町方の道空間の存続と「持場」
}

- 南伝馬町二丁目他三町を事例として -

\section{MAINTENANCE OF STREET SPACES AND MOCHIBA (POSTS OF RESPONSIBILITY) IN EDO COMMONERS DISTRICT}

- A case study of Minami tenma chō 2, Minami saya chō, Minami nushi chō, and Matsukawa chō $1 \cdot 2$ -

\author{
高 橋元 貴*1
}

\section{Genki TAKAHASHI}

\begin{abstract}
Street spaces in the commoners district (chōnin-chi) of Edo were managed and owned by shogunate. But the streets were maintained by the chōnin (commoners). The task of maintaining street spaces (street functions and public safety) was assumed both in terms of workload and cost by the towns along the street, and the range managed by each town could be spatially. This paper gives a discussion of Mochiba (the posts of responsibility) that were spatial divisions to the town's management of street spaces and the feature of spatial maintenance system.
\end{abstract}

\section{Keywords : Edo, Chōnin-chi, Chō, Street Spaces, Maintenance, Mochiba} 江戸，町人地，町，道，維持管理，持場

\section{1. はじめに}

本稿の主眼は、城下町江戸の物理的環境の存続のありようを歴史 的に考えるために、道の維持管理負担にみられる町共同体による空 間的な分業体制（「持場」）の実態とその特質を、個別町分析から跡 づけることである。

都市の基盤施設であるインフラ・ストラクチャー（道や堀川、橋 など。以下「インフラ」と略す）の多くが、都市住民（武家・寺社・ 町人）による管理と費用負担とによって維持されていたことは、す でに戦前期から注目され、地縁的・自治的な管理組織としての町共 同体や武家方組合の存在が指摘されていた 1)。しかし、その実態に ついては長らく不問に付され、90 年代以降の日本近世史分野を中心 とする都市社会史研究のなかで多くの成果がだされてきた2)。

町人地に関しては、町政運営の実相を「町入用」の分析から概括 し、番屋や木戸、井戸や芥溜といった町内に存在した多様な共同施 設の利用や管理のあり方について幕府法令や規制策を通して論じた

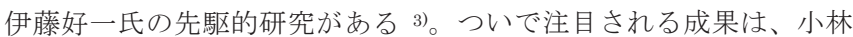

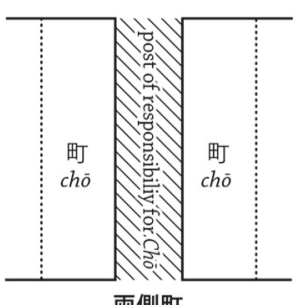

両側町 (Both-side town) Fig.1 Mochiba (Posts of Responsibility)
信也氏の所論である ${ }^{4)}$ 。小林氏は、個別町や広小路の事例分析をも とに「江戸市中の道路には持場という区分が設定され」ており、「道 路区分に面して敷地を持つ町や寺社、武家」が、当該エリアの維持 管理を負担していたとする「持場負担」論を提起し、その主たる内 容が治安維持（「異変処理」など）と機能維持（「道造」など）とに 大別できるとした（Fig.1）。

こうした屋敷の地先部分の道を当該の屋敷所持者ないし拝領主が 維持管理の責任を負う「持場負担」の原則は、町人地をはじめ、武 家地や寺社地においても敷衍化しうることは寸でに先行研究のなか でも確認されており、筆者も異論はない。しかし、町の持場に限っ てみても、以下の諸点において検討の余地が残されていると考え、 これを本稿の具体的な課題としたい。

第一に、持場負担」という原則はいつから成立したものであった のか。すなわち、持場が、幕府によって上から設定されたものであ ったのか、また、幕府の管理体制のなかでどのような位置を占めた のかについてはこれまで論じられていない。

第二に、維持管理が、個別町に対応寸る空間的な分業体制(「持場」) に基礎づけられていたことはしめされたものの、町共同体によって 負担されていたという理解に留まっており、個別具体的な検討によ るその空間的特質の解明は十分になされていない。

\section{2. 道空間の管理体制と「持場」}

「持場負担」の原則は、幕府（町奉行）による道空間の管理体制 のなかでどのような位置を占めていたのであろうか。ここでは拙稿 の議論を確認したうえで少しく考えてみたい5)。
$* 1$ 東京大学大学院工学系研究科建築学専攻 特任助教・博士 (工学)
Research Assoc., Dept. of Architecture, School of Engineering, The University of Tokyo, Ph.D. in Eng. 
各町内の道における治安維持（異変処理）と機能維持（道と下水 の保全・修復）を町中へと命ずる触は、17 世紀半ばから見出すこと ができる ${ }^{6)}$ これらは、明暦大火後（1657 年）の市中の防火政策と あいまって、(1)「番」の徹底（木戸番・自身番・中番など）、(2)手桶・ 水溜桶・梯子の設置と修復、(3)「道造」（道の修繕）と材木類の高積 や店前・軒先への積置の禁止の 3 ケ条として寛文年間（1661～72 年) に定式化されるにいたった7)。

そもそも町人らの生活に直結寸る道空間の維持管理、具体的には 共同施設（道・下水、木戸・自身番屋・井戸・下水など）の運営は、 町ごとの自律的な活動の所産であった。すなわち、公儀の地所であ るはずの町方の道空間は、幕府によって直接管理されたわけではな く、町人らの負担によって存続したのである。こうした自治的な仕 組みが、町方における 17 世紀末ころからの不在地主化にともなう 「町中」の形骸化をへながらも、町の共同体としての紐帯関係を持続 させる重要な役割を担ったことは間違いない8)。

他方、幕府側（町奉行）が町人地支配の末端に、町政機構を位置 づける一環として、道の維持管理負担を町触のかたちで町人らに課 すことで市中の空間管理体制を整備していったという側面も看過す ベきではないだろう。ここでは、 17 世紀後半の町触では「町中申合」 つて維持管理を行うべきとするのみで、各町が負担すべき空間的範 囲がいまだ明示的ではなかった点に留意しておきたい。

上述の触を基本的内容としながら、18 世紀中ごろから整えられて ゆく町方における道空間の管理体制が、拙稿で明らかにした「往還 二相拘リ候儀」の認可システムである。これは、寛保・延享期 (1741 ～47）に初期的な動向を見出せ、明和 5（1768）年の道奉行廃止に ともなう町奉行による町方における道空間支配の確立をへて、寛政 $2 （ 1791 ）$ 年の「町法改正」の際に確立された。これにより、町人 地 =町奉行支配地において町奉行と普請奉行（・道奉行）の管理権 限が複層していた状況が解消され、道空間における「往還二相拘リ 候儀」のそれぞれの許認可先が、町奉行と普請奉行とに明確に分離 されたのである（Table 1)。

かくして 18 世紀末、町人地の道空間の管理体制が一応の完成を みたといえる。しかしこれは町奉行による一元的統制を意味したわ けではなかった。Table1から明らかなように、以後も町人地におけ る道空間管理の一部（道造や上水など）は普請奉行によっても管轄 されていた。すなわち、幕府による町方の道空間管理の内実は、近 世をとおして町奉行一町、普請奉行（道奉行）一町という 2 つの所 轄系統が併存する状況にあったのである。

では、町人地内の道を、町を単位として空間的に分割し、これを 「持場」として当該の町に負担させるというあり方は、上述した「往 還ニ相拘リ候儀」の認可システムの形成とはどのような関係にあっ たのであろうか。

\section{[史料 1 ] 9)（下線は引用者）}

一、町々往還道悪敷場所間々相見候間、御成道は勿論、其外共 不打捨置、相応二取繥、人馬車通行差支無之様可致候、猥二致 置候八〉可為越度候

但、片側町方持場二候八、、向側道造無之候共、道悪敷場所 は町方持場之分斗道造可致候
Table1 Contents and filing destinations for applications submited in Kansei 3 (1791)

申請項目

(Contents)

出願先

(Filing Destinations)

木戸・番屋并駒寄纏建など之儀

(new construct and repair wooden town gates andtown police boxes, fences etc.)

町方家前下水、右新規修復共

(new construct and repair sewer drains in front of Machiya)

町方持橋願

(bridges managed by the town)

火之見建梯子并火之見櫓建候願

(new construct fire loolout tower and ladder)

家前板囲・土置場願

(board fences on construction sites and soil stockpiles)

看板柱建候願

(standing signboards)

紺屋共家前江物干柱建候願

(establishment of drying areas by dyers)

質屋共御用中家前江虫干致候願

(airing out of clothes by pawnshops when orderd by the shogunate)

商ひもの家前江積置并日覆願

(piling products in front of machiya and putting up sunshades)

下水外流し仕付并駒寄矢来建候願

(building sinks, fences, and palisades outside of the sewage gutter)

店前輪木建候願

(setting wood for placing under heavy items in front of machiya )

町方河岸付石垣并川内江も䀣り相当願

(items related to stone walls and canals)

雛甲人形商ひ候内往還江小屋掛ヶ願

(stacks for selling girls and boys day dolls out on the street)

神事二付幟桃灯建候願

(setting up strings of lanterns during festival)

掘井戸之儀二付願

(water wells)

道造

(roadworks)

車留願

(traffic control /street closures)

町方往還横切下水、右新規修復共

(construction and repair sewer drains case where sewer system

stretches across the street)

武家町組合橋願

(bridges managed by samurai)

上水井戸普請など都而上水二付候願并届訴

(all items related to water supply)

* made from Ruiju-senyo (『類集撰要』3,35・36件 [旧幕])

これは宝暦 8（1758）年 7 月 28 日、町年寄を通じて町中に下達 された触で、町人地内に「往還道悪敷場所」が散見されることを理 由に、将軍の「御成道」はもちろん、その他の道についても適切に 修繕し、交通に支障がでないようにと指示している。注目すべきは 下線部の但し書き部分で、道の「片側」が「町方持場」のとき、「向 側」(寺社・武家) による道の修繥が行われていなくとも「町方持場 之分」のみは町が普請を行うようにとされている。

ここから、町が維持管理すべき空間的範囲、すなわち町の「持場」 を前提として触が出されていることは明らかだろう。また、通りを 挟んで武家屋敷や寺社と面するような町の場合には、道の中央を境 に半分のみを当該の町が負担す心゙きと考えられていたこともわかる。 町が負担する持場の空間的範囲にまで言及した道造令は、史料 1 が

『江戸町触集成』のなかでは初出である 10)。

つぎに掲げる史料は、天明 5 （1785）年 5 月 24 日に庇地規制令 とあわせて達せられた道造に関する申渡の一節である。近年、町人 らが「銘々勝手」に道の修繕を行っているため、町内の道にくぼみ が多く「夜中往来之差障二相成、其上雨天之節は地窪之所江水落込」 み、また「泥芥等下水江押流」れることで下水も埋まってしまって 


\section{[史料 2] ${ }^{11)}$}

一、道造之儀も近比は銘々勝手二道造致候故高下有之、其上両 側町屋之分は相互二障候故、高下相応二も造候得共、御堀端又 は向側武士屋鋪之場所は、町屋之方下水江庇を出し、向側江水 落候様道造いたし候場所有之、不届之至二候、己来往来道造之 儀も、右之心得を以不㘧之儀無之梯普請可致候、尤廻り之者差 出、不相守者於有之は、吟味之上急度可申付候事

両側町の場合は、双方に支障が出るため路面の「高下」なしに修 繕が行われているようだが、「御堀端又は向側武士屋鋪」である町で は、店前の下水（の外側）にまで庇を張り出し、「向側」に排水され るように道造をしている場所もあるとされている。ここでもやはり 町奉行側が、両側町か否かという支配にもとづく町の空間形態に蕉 じた「持場」の存在を認識していたこと、さらに、町人地における 道路の質的状態についても関知していたことがわかる。また、通り の片側のみに展開寸る町の人びとが、字義通り道半分のみを負担す れば良いことを逆手にとって道の整形を行っていたこと、つまり、 物理的にも片側半分のみが町によって修繕されていた実態がうかが え興味深い。

町の持場の空間的範囲にまで踏み込んだ内容をもつ町触は、上記 以外は管見の限り見出せていない。しかし、ここからは町奉行側が 「持場」という空間的な負担のあり方を 18 世紀半ばに強く認識し ていたことはうかがえよう。他方、町人地や武家地、寺社地が入り 組む場所での維持管理の負担をめぐる争論をみる限り、町奉行をは じめとする幕府役人（普請奉行・寺社奉行など）が「持場」負担を 念頭において道空間管理を体系づけていたことは間違いない 12)。

以上、限られた史料からではあるが、町方における「持場」の成 立と幕府の管理体制のなかでの位置づけを、つぎのように仮説的に 提示しておきたい。

「持場」とは、それぞれの屋敷に付随する地先権がおよぶ範囲に 相当すると考えられ、「町」の共同性と排他性にその深淵をもつもの で、幕府によって上から設定され た原理ではなかったと思われる。 冒頭でみた 17 世紀後半の町触は、 こうした中世由来の町共同体の存 在形態を前提に、町人地における 道の管理体制を整えてゆく初期的 な政策と理解できるだろう。以後 も持場負担は明確には法制度化さ れなかったが、18 世紀中期以降の 「往還二相拘リ候儀」の認可シス テムの構築や道にそくした町方支 配領域の明確化と、同時期におけ る「持場」の空間的範囲を明示し た町触とはパラレルな関係にあっ たと推定される。幕府 (町奉行)

は、それぞれの町に「持場」を割 り当て、負担関係を整序すること で町方における道空間の統制を図

\section{3. 個別町にみる「持場」の実態}

つづいて、町が負担した持場の実態を、江戸町方の中心部に位置 する日本橋南地域の名主・高野新右衛門家が支配した町々（南伝馬 町二丁目 - 南鞘町 - 南塗師町 - 松川町、以下「南伝馬町二町目他三 町」と呼ぶ）を事例にみていきたい13)。

国役・公役などの役負担をふくむ各町の自治的な運営費(「町入用」) は、狭義の町人、つまり町屋敷所持者（地主）が、彼らの所持する 町屋敷の間口（軒役）に応じて負担することが一般的であった。

南伝馬町二丁目他三町については、寛政 $3(1791)$ 年 6 月に町年 寄役所に提出された「町入用掛り高書付」(以下「町入用書付」と呼

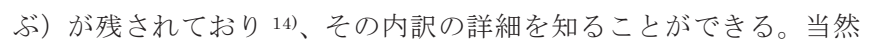
ここには町内の道空間の維持にかかる支出もふくまれている。

同史料はすでに伊藤好一氏がその内容を分析し、道の維持管理に 関わっては、小林信也氏が持場負担に対応する項目を町入用のなか から抽出できるとしている ${ }^{15)}$ 。しかし筆者は、こうした指摘のみで は町の持場の実態把握としては不十分と考える。町はそれぞれ独自 の町政機構を有したが、道を挟んで、あるいは背中合わせに他町と 隣接し、町内の道空間は多様な構成要素一道路、上下水、木戸、番 屋、井戸など—から成る。それゆえ、各町中による負担を大枠とし ながらも、こうした物的な環境条件のありようが、維持管理の個別 的な負担関係を規定したと想定され、持場負担の内実は、かならず しも町入用に現れるような共同体的な負担関係のみで説明しえるも のではなかったと考えられるからである。

そこで、町による道空間の維持管理業務のなかでもつとも基本と なる「番」(自身番・木戸番)による町内の警固（治安維持）と道・ 下水の修復（機能維持）を題材に、町の持場内における負担関係の 実態を検討してみたい。Fig.2 は、宝永 7 （1710）年の沽券図をも とに、18 世紀における南伝馬町二丁目他三町の空間を、木戸や下水 などの情報もふくめて復元したものである。以下これをもとに考察 をすすめる。

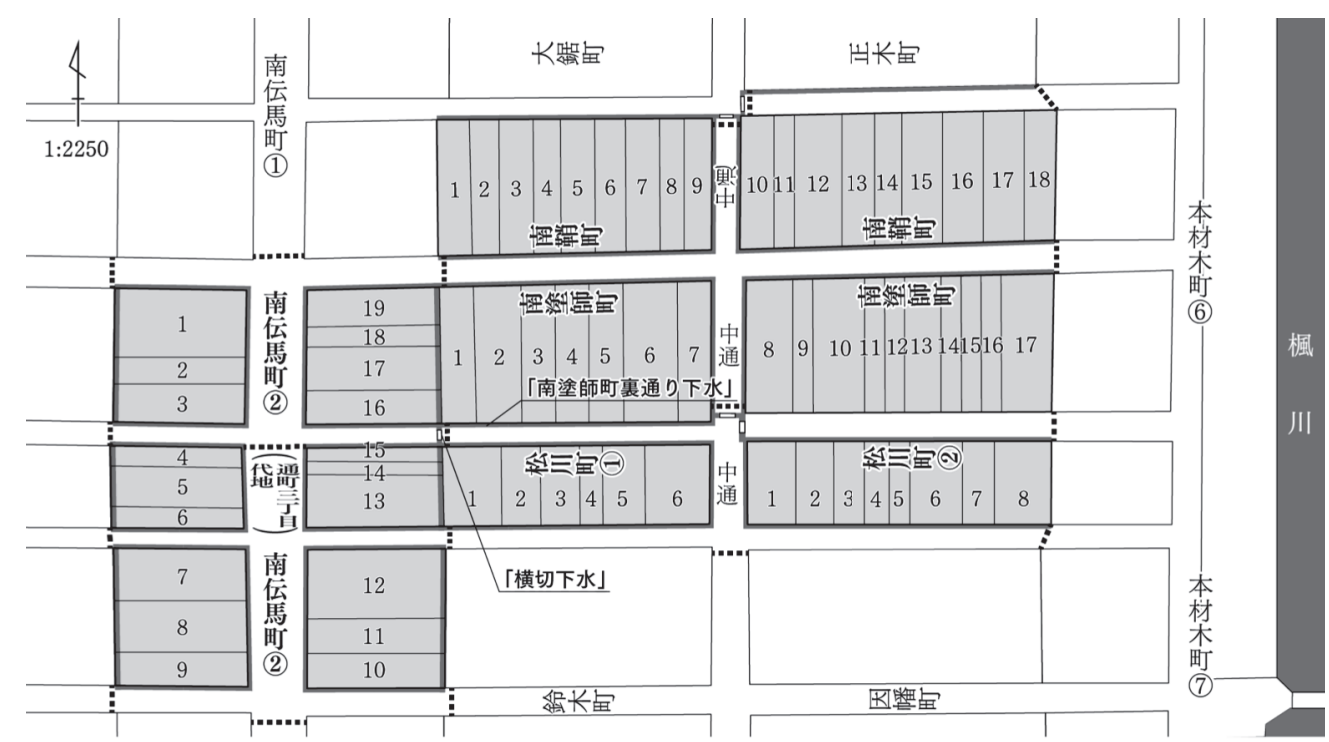

Fig.2 Minami-tenma-cho 2, Minami-saya-cho, Minami-nushi-cho, and Matsukawa-cho (18th century) 註: 「五千分之一東京実測全図」(『五千分の一江戸東京市街地図集成』柏書房, 1992年) をもとに「活券御改御与力衆江指上候脍図控」 (『中央区沿革図集 京橋編』東京都中央区立京橋図書館, 1993年) 上り作成.

凡例： $\square$ 高野新右衛門家の支配する町々 ……... 木戸 下水 $\square$ 橋 


\section{1. 木戸・自身番}

町には木戸門が設けられ、町内での喧嘩口論や倒者などの異変処 理は、町屋敷の家主ないし町に抱えられた番人によって担われた。 その拠点は、木戸際に設けられた木戸番屋や、町内の路上に設置さ れた自身番屋であった（なかには町屋敷の一部を町中が借地・借家 して自身番屋とする場合もあった)。

町入用書付のなかには、「自身番屋入用」（南伝馬町二丁目・南塗 師町・松川町)、「自身番店賃」(南鞘町・南塗師町)、「木戸番給」・「木 戸番法被代」(南鞘町・南塗師町)、「自身番一ヶ所木戸番屋二ヶ所普 請修復畳替并諸雇人足賃」(南伝馬町二丁目・南鞘町・南塗師町・松 川町）などの項目を見出せる。これらが町内の「番」に関わる町中 の負担にあたる（業務費用や番人に対する給与、木戸・番屋の物品 費や修繕費など)。ここから、18 世紀末の南伝馬町二丁目他三町に は、それぞれ自身番屋が 1 ケ所、木戸に付随する木戸番屋が 2 ケ所 あったことがわかる（ただし、南鞘町・南塗師町については両町で 自身番屋 1 ケ所、木戸番屋 2 ケ所であったと推定される)。こうし た道の治安維持にかかわる費用は、町屋敷所持者である狭義の町人 ＝地主が、所持する町屋敷の間口の広さを基準（間口割）として負 担していた。

木戸や番屋の数とその位置は、近世を通じて変化もみられたが、 治安維持にみる町の持場とは、町境に設けられる木戸によって仕切 られた空間的範囲に相当すると解してよいだろう（Fig. 2)。なお、 南鞘町・南塗師町のようにそれぞれの町が道を隔てて向かい合う場 合は、両町が費用を拠出することで両側町と類似した持場を構成し ていたと理解される。

ところで、南鞘町・南塗師町の「中通」の端に設けられた木戸の 普請入用は、間口割りによる町人＝地主らの支出に加えて、「中通」 に面する角屋敷所持者＝地主らが「角役銭」(総費用の十分の一）を 追加で支払っていたとされる16)。また両町では、自身番屋の普請や 番人給与についても、同種の「辻番銭」や「中番銭」が別途設けら れていた。そもそも角屋敷は、町内の有力な町人が所持する場合も 少なくなく(名主であった高野新右衛門は、南伝馬町二丁目〈Fig. 2 の屋敷 $1 〉$ の居付地主)、沽券金高も他の屋敷（「中屋敷」）にくらべ 高かった。こうしたいわば町屋敷の地価に応じた負担に対する重み 付けが、町共同体のなかで取り決められていたのである ${ }^{17) 。}$

ここで空間的な観点から留意しておきたいのは木戸の位置につい てである。というのも、木戸は町境に設置され、それぞれの持場の おおよその境界を明示寸ることから、木戸そのものの維持をめぐっ ては隣接町との関係が必然的に生じたと想定されるからである。

松川町と、その南側にある鈴木町（18 世紀中の支配名主は源七） との町境には、番屋を付随させた木戸が松川町側にあったが、寛延 2 （1749）年の破損をきっかけに、修復にあわせてその位置が鈴木 町側へと引き直された ${ }^{18)}$ 。この「場所替」に関しては、松川町・鈴 木町の月行事が連署して町奉行所宛に願い出ていることから、両町 での何らかの合議があったことは間違いない。普請入用の負担割合 については未詳だが、町の境界装置となる木戸については、設置場 所に関する隣接町相互の「申合」をはじめ、費用の分担などもなさ れていたと推定される。そして、木戸の設置場所が、それぞれの町 が負担する「番」の具体的な空間的範囲（「持場」）にも直接影響を 与えたと考えられる。
以上から、道の治安維持に関わる諸経費は、大局的には町屋敷を 所持する町人＝地主たち、つまり町中によって一律に賄われたとい えるが、角屋敷所持者に追加で賦課される「角役銭」のような特別 な賦課規則も存在していた。とくに町の境界装置となる木戸は、持 場の空間的範囲を物理的に明示寸るものでもあって、その普請や修 復については、各町のみでは完結せず、隣り合う町との合議や取り 決めが不可欠であったといえるだろう。

\section{2. 道}

道路の修繥、補修を意味する「道造」や「道繥」(以下、「道造」 と統一）といった支出項目も町入用書付のなかに見出せる。いずれ も「臨時入用」とされていることから、南伝馬町二丁目他三町にお ける道造は不定期に実施されていたようである。

道造を負担すべき場所、つまり機能維持に関わる持場もまた、お おむね木戸・自身番と同様の範囲であったと考えられる。道を挟ん で向かい合う南鞘町と南塗師町は、それぞれの町屋敷の地先部分に あたる道半分ずつを分担していたことになろう。

享保 $13(1728)$ 年 5 月、町年寄から町中に対し「町内横町道造」 の費用支出についてお尋ねがなされた ${ }^{19)}$ 。「町内横町」の道とは、 各町の表通りに直交する横道（「中通」）のことである（Fig.2）。南 伝馬町二丁目他三町の月行事からの返答によれば、いずれの町にお いても「町内横町道造」の費用は「町内」ではなく、「中通」に面す る町屋敷（「両角屋敷」）を所持する町人二地主によって独自に負担 されているという。すなわち、町入用書付にあらわれる「道造入用」 とは、表通りのみのものであったということになる ${ }^{20)}$

これは費用負担の点からみれば、木戸・自身番でみた「角役銭」 と同様の賦課形式といえる。しかし、「町内」としての負担は表通り に限られており、物理的には町空間のなかに包摂されるはずの「中 通」に限って「角屋敷」の町人のみにその機能維持の責任の一切が 委ねられていたというあり方は特筆に値しよう。

\section{3. 下水}

江戸の町屋敷には「家前雨落下水」が設けられていることが一般 的で、屋敷境界や町の背割りとなる地尻にも下水が設置される場合 もあった。こうした町における下水網の実体は十分には明らかにさ れていないが、沽券図の記載にしたがえば、南伝馬町二丁目他三町 では街区の四辺を 2 3 尺ほどの下水が囲繞していたことがわかる

(Fig.2)。いくつかの下水は町内の道を跨いで連結されており、東 側に流れる楓川（本材木町側）へと注いでいたものと思われる。た だし、町方におけるすべての下水が、最終的な排水先をもつような ネットワークのもと構築されていたとは考えにくいだろう。

町入用書付をみると、南伝馬町二丁目と松川町には「下水浚入用」 なる項目を見出せ、道造と同じように、各町が町内にある下水の維 持管理を担っていたことがわかる。他方、南鞘町・南塗師町につい ては「組合持大下水修復并浚入用」が計上され、下水管理に関わる 「組合」なるものの存在がうかがえる。この「組合」ならびに「大 下水」の位置については未詳だが、向かい合う町どうしであった両 町が、それぞれ同等の費用を拠出しあっていたものと推定される。

ここで具体的にとりあげてみたいのは、南塗師町西側の町屋敷裏 を流れる下水 (「南塗師町裏通り下水」) と、南塗師町と松川町との 間の道を跨いで流れる下水(「横切下水」)についてである (Fig.2)。 延享 3 （1746）年 5 12 月にかけて、両下水の維持費用の負担をめ 
ぐって南塗師町と南伝馬町二丁目、通三丁目代地の町人＝地主との 間で争論が起きており、その経緯はつぎのようであった ${ }^{21)}$

-「南塗師町裏通り下水」の浚費用は、4 割を南塗師町西側の地 主（Fig.2 の屋敷 1 7）が、通りを挟んで南側に位置する松川 町一・二丁目が残る 6 割を負担することになっていた。

- 通三丁目代地東側の町屋敷（屋敷 $13 \sim 15$ ）の地尻を流れ「南塗 師町裏通り下水」へとのびる「横切下水」は、当地に代地が設 定された元禄 4 （1691）年に通三・四丁目の支配名主から南塗 師町への申入れによって新たに敷設されたものであった。

・ その際、「南塗師町裏通り下水」へと「水落」することから、南 塗師町西側（屋敷 1 7) の地主から「浚入用」出銭が要求され、 以後「通三丁目代地十二間」（屋敷 $13 \sim 15 ）$ の地主が、「南塗師 町裏通り下水」の浚費用の一部を負担することとなった。

・ その後の寛保元 (1741) 年、「南塗師町裏通り下水」の浚土処理 のための「船積」費用の一部負担を、南塗師町西側の地主（屋 敷 1 7) が通三丁目代地東側の地主（屋敷 13１5）に対し掛 け合ったが、これを拒否された。

- 他方、南伝馬町二丁目北の東側町屋敷（屋敷 16 19）の裏を流 れる大下水も「南塗師町裏通り下水」を「落口」としていたが、 当該地主は「下水浚費用」を「古来」より負担していなかった。

・ こうした不均等な負担関係の改善をもとめて、延享 3 (1746) 年 5 月、「南塗師町四拾間之町人」(南塗師町西側の地主 7 名) が、「南伝馬町二丁目十二間之町人」(通三丁目代地東側の地主 2

名）と「同町弐拾間之町人」（南伝馬町二丁目北の東側の地主 4

名）を相手取り、町奉行所に出訴におよんだ。

上の経緯から指摘できるのは、つぎの 4 点である。

第一に、そもそも「南塗師町裏通り下水」の維持管理が南塗師町 の町中全体ではなく、同町西側の「四拾間之町人」（屋敷 1 7）に よってのみ負担されていたことである。これは同町東側にある町屋 敷（惣間口 46 間半、屋敷 8〜17）の地尻には下水が存在しなかっ たことによるものと考えられる。

第二に、「南塗師町裏通り下水」が、南塗師町西側の地主だけでは なく、道を挟んで南に位置する松川町と共同で維持管理されていた ことである。そもそも松川町は、日本橋南地域に位置する川瀬石町 と南油町の代地の一部として元禄 4（1691）年に当地で成立した町 であった。この点を勘案すれば、「南塗師町裏通り下水」の負担関係 が、代地町の設立にともなって南塗師町西側の地主と松川町との間 で新規に取り決められたものと推定することができよう。また出資 割合が折半ではないことから (南塗師町西側 $=4$ 割、松川町 $=6$ 割)、 松川町一・二丁目（惣間口 86 間半）の地主がともに支出していた と考えられる。

第三に、「南塗師町裏通り下水」の維持管理負担めぐる通三丁目代 地と南伝馬町二丁目の分担方法についてある。通町三丁目代地は、

元禄 3 （1690）年まで当地に存在した長崎広小路が再開発されたも ので、明暦大火後に火除明地設置のために町屋敷を上地された通三 丁目に与えられた替地であった。この代地町は、南伝馬町二丁目の なかほどに位置し、町屋敷はわずか 6 筆にすぎなかったが、設立時 は南伝馬町とは別の自立したひとつの「町」であった。しかし享保 6 （1721）年までに、この 6 名の家持（居付地主）は、南伝馬町二 丁目の町中に加わり、同等の町役と御伝馬役を勤めることとなり、
通三丁目代地は南伝馬町二丁目の一部となった ${ }^{22)}$ 。

この通三丁目代地のうち東側の地主は、「横切下水」設置の対価と して「南塗師町裏通り下水」の浚費用の一部を負担することとなっ ていた。しかし、南伝馬町二丁目東側の町屋敷裹の下水にも「南塗 師町裏通り下水」への「落口」が設けられていた。排水構造として は通三丁目代地東側の「横切下水」と同様の関係にあるにも関わら ず、南伝馬町二丁目東側の地主は「南塗師町裏通り下水」の浚費用 を負担していなかったのである。

第四に、この争論をめぐる当事者（「訴訟人」・「相手」）について である。「南塗師町裏通り下水」は、南塗師町では西側の地主によっ てのみ負担されていた。ゆえに、この争論の訴訟人は南塗師町の町 中ではなく、「南塗師町四拾間之町人」（屋敷 1～7）なのである。対 する訴訟の「相手」もやはり、「南塗師町裏通り下水」に直接の排水 路をもっていた町屋敷の所持者である南伝馬町二丁目と通三丁目代 地の一部の地主であった。

この一件の顛末を述べておくと、「南塗師町裏通り下水」の浚入用 は、その 9 割を南塗師町西側の地主が、残る 1 割を南伝馬町二丁目 北の東側と通三丁目代地東側の地主が負担すること、南塗師町の「中 通」にある「往来下水四間」の浚入用および「石垣板・堰板」の普 請入用については、南塗師町西側の 40 間、南伝馬町 2 丁目北の東 側 20 間、通三丁目代地東側の 12 間の「牢小間七拾二間二割」って それぞれの地主が負担すること、とされた。なお、詳しくは不明だ が、これらは南塗師町裏通り下水の浚入用総計の 4 割にあたり、残 る 6 割は松川町一・二丁目が負担したと思われる。

このように町屋敷に沿って流れる下水は、町内に一様に敷設され ていなかったこともあって、個別の町中による負担を基礎としなが らも、その負担関係は必ずしも「持場」という閉じた領域に収まる ものではなかった。そのため、町の成立や下水の敷設経緯、下水の 排水方向に依拠した個別の地主たちによる負担関係が、町の持場を 越えて独自に形成されていたのである。

\section{4.むすびにかえて——町の「持場」の特質}

以上から、町の「持場」の特質はつぎのように整理できよう。

(1) 町方における道の維持は、町共同体 (「町中」)、すなわち、狭義 の町人（地主）によって負担され、その範囲となる「持場」と は、各町屋敷の地先部分の加算的集合であって、おおむね町境 を枠とする領域を意味した。

(2) 幕府 (町奉行) は、各持場における負担をそれぞれの町に課し、 役所への認可と届出を行わせ、かつ、相互の負担関係を調停す ることで、町人地における道の維持管理体制を構築していた。

(3) 各町の持場では、当該町の主たる構成員である町人（地主）に 対し、基本的に間口割りなどによる均等な負担配分がなされて いた。しかし、特定の町人らに対する追加賦課も取り決められ ており、負担配分は必ずしも町内で均質なものではなかった。 また、負担関係が町内で完結せず、隣接する町や町人との相対 で、それぞれの持場を横断するような地縁的な関係も形成され ていた。

(4) 持場を逸脱する維持管理をめぐる負担関係は、木戸や番屋、道 路や下水といった多様なインフラの機能維持の局面に特徽的に 見出せる。すなわち、持場内の負担実態は、それぞれの道空間 
を構成する物理的諸条件に強く規定されるものであった。

町方における持場内の維持管理業務は、大きくは治安維持 (「異変 処理」）と機能維持（「道造」）とに分類できるが、最後に、町の持場 が新たに設定（拡張）される局面に着目することで、両者が別の位 相として分離しえたことを指摘してむすびとしたい。

明暦の大火後、江戸城周辺や町方中心部では、「御用地」として町 地が召し上げられ、延焼防止帯として火除明地・広小路が多数設け られた ${ }^{23)}$ 。しかし、実際にはこうした明地には床店や臀筫張の店舗、 芝居小屋、水茶屋などが建ちならび、江戸の「盛り場」となってい ったことはよく知られている 24)。しかし筆者は、火除明地や広小路 が、幕府の管理上、あくまでも町内の道（「通り」）と同質のものと して扱われていたことを重視したい25)。町方に設定された広義の道 空間＝明地は、助成地として請負町人によって独自に管理・運営さ れる場合もあったが 26)、明地沿いの町々に「預ヶ置」かれる場合も 少なくなかった。つまり幕府は、明地固有の管理体制を設けること はせず、基本的に既存の持場負担の原則を念頭において、道空間の 統制を行っていたと考えられる。

ここでは日本橋北と内神田とを隔てる神田堀北岸一帯に存在した 火除明地を例にとりあげよう。この火除明地は、神田堀北岸の町々 の類焼を直接の契機として享保 4〜7（1719～21）年にかけて断続 的に設置され、隣接する町々（神田鍛冶町・神田佐柄木町・元乗物 町・神田紺屋町など）の地先にあたることを理由に「預ヶ置」かれ た 27)。このとき明地を「預ヶ置」かれた町々は、「捨物倒者見守」、 つまり明地内の治安秩序の維持にかかる費用を負担する助成として 「床番・商番屋」の設置を町奉行所に出願し、許可されていた。

その後の享保 15 （1729）年 8 月、当明地沿いの神田鍛冶町・神 田佐柄木町・元乗物町・神田紺屋町などが、「明地前往還之道」が「殊 之外悪敷人馬通路」が困難で「道造可仕者」がいないため、明地を 預かる町々で以後の道造（「永々道造」）を負担する対価として計 6 ヶ所の商番屋設置を新たに町奉行所に出願し、これも許可された。

注目す心゙きは、明地を「預ヶ置」かれた町々が、当初は明地内の 道造をも担うべきとは認識していなかった点である。つまり、明地 内は当該の町々にとっては治安維持を負担す心゙き「持場」でしかな かったのである。そもそも町奉行が命じた「預ヶ置」が意味すると ころは曖昧だが、享保 15 年の出願が認可されていることから、こ の火除明地に関していえば、異変処理（治安維持）と道造（機能維 持）とが、別々の負担として町に課されたことは間違いない。

この事実は、一体的にみえる町の「持場」が、治安維持と機能維 持とに分離されうるものであったこと、さらに維持管理すべき内容 ごとに負担者（町や町人、請負人）が設定され、同一の道空間上に 位相の異なる「持場」が重層的に展開した可能性を示唆している。

\section{注}

1）後藤新平『江戸の自治制』（二松堂書店, 1922 年），幸田成友『江戸と大 坂』(冨山房, 1934 年) など.

2）以下にあげる江戸の武家地における研究進展が目立つ. 岩淵令治『江戸武 家地の研究』(塙書房, 2004 年) , 藤村聡「近世後期における江戸武家屋敷 の上水・橋々組合について」(『歴史学研究』682, 1996 年), 松本剣志郎「江 戸武家屋敷組合と都市公共機能」(『関東近世史研究』57, 2004 年)など.

3）伊藤好一『江戸の町から゙』(平凡社, 1986 年), 同「江戸町入用の構成」(『江 戸の民衆と社会』吉川弘文館, 1985 年).

4）小林信也「近世江戸市中における道路・水路の管理」（『江戸の民衆世界
と近代化』山川出版社, 2002 年, 初出 1996 年), 同『都史紀要 42 江戸の広 小路—その利用と管理』(東京都公文書館, 2014 年) など.

5）拙稿「江戸町人地における道空間の支配と管理体制」（『日本建築学会計 画系論文集』729 号, 2016 年 11 月).

6)『江戸町触集成』第 1 巻, $377 \cdot 465 \cdot 637 \cdot 688 \cdot 797$ 号(塙書房, 以下『江 町触』と略す)。

7）定式化された町触の初出は，延宝元 (1744) 年 9 月 29 日である(『江町触』 第 1 巻, 1146 号)

8）伊藤毅「町共同体施設」（『日本都市史入門Ｉ空間』東京大学出版会, 1989 年). 17 世紀後半以降の江戸町人地では居付地主層が減少, 寸なわち, 不在 地主化がす寸み, 実際の町政を担ったのは本来の町人=地主の代替者とな る「家守」たちであった（吉田伸之「町人と町」『近世都市社会の身分構 造』東京大学出版会, 1998 年, 初出 1985 年).

9)『江町触』第 6 巻, 7282 号.

10）江戸橋南西に位置した坂本町には同町が負担する「持場」の範囲をしめ 寸延享 $3(1746)$ 年の絵図が残されており，18 世紀前半には持場負担の原 則を幕府側も認知していたものと考えられる(『坂本町旧記』旧幕府引継書, 国立国会図書館所蔵、以下「旧幕」と略す)。

11)『江町触』第 8 巻, 9069 号.

12)『撰要類集』(旧幕)には数多くの持場をめぐる争論を見出すことができる.

13）高野家支配下の町々について, 包括的かつ多角的に論じたものとして吉 田伸之氏による以下の論考がある. 吉田「江戸南伝馬町二丁目他三町の町 制機構と住民」，同「役と町」（『近世巨大都市の社会構造』東京大学出版 会, 1999 年. ともに初出は 1979 年), 同「第 2 章 南伝馬町」(『都市一江戸 に生きる』岩波書店，2015 年). なお，本稿で用いる「南伝馬町二丁目他三 町」という呼称は，上記吉田論文にならうものである.

14）『東京市史稿』市街篇, 第 31 巻, 18 47 頁.

15）前掲註 3）伊藤「江戸町入用の構成」，前掲註 4）小林「近世江戸市中に おける道路・水路の管理」

16)『撰要永久録』公用留, 巻之 4 , 第 67 件「角屋鋪前道造并出銭之義尋」（東 京都公文書館所蔵）。

17）同上によれば，南伝馬町・松川町では「角役銭」は設けられていない.

18）『撰要永久録』公用留, 巻之 5 , 第 94 件「松川町木戸番屋場所替」.

19）前掲註 16）史料。

20)「辻番銭」・「中番銭」が存在した南鞘町と南塗師町でも「横町道造」に 限っては，角屋敷の所持者のみによって負担されており町入用としては算 出されていなかったと考えられる.

21）『撰要永久録』公用留, 巻之 5 , 第 93 件「南塗師町下水浚入用割 附り済 口證文為取替證文」。

22）前掲註 13）吉田「江戸南伝馬町二丁目他三町の町制機構と住民」によれ ば，当初南伝馬町二丁目が勤める御伝馬役も負担せず，元地である通三丁 目の町役 (公役金) のみを勤めていたが，宝永 7 （1710）年の南伝馬町二 丁目町中による町奉行所への出訴の結果, 正徳 2（1712）年には通三丁目 代地の家持 6 名も御伝馬役の一部を負担することとなった. その後の享保 6 (1721) 年 12 月には,南伝馬町二丁目と同等の御伝馬役を勤めることにな り，内実ともに通三丁目代地は南伝馬町二丁目に「同質化」したという.

23）千葉正樹「御府内沿革図書に見る江戸火除地の空間動態」(『東北大学国 際文化研究科論集』9 号, 2001 年) など.

24）前掲註 4)，吉田伸之『21 世紀の「江戸」』(山川出版社, 2001 年), 同「両 国橋と広小路」(『江戸の広場』東京大学出版会, 2005 年), 横山百合子「江 戸町人地社会の構造と床商人地代上納運動」(『明治維新と近世身分制の解 体』山川出版社, 2005 年, 初出 1999 年) など.

25）『明和撰要集』 7 上，「道敷下水之部」，第 2 件（旧幕）および『江町触』 第 7 巻, 8152 号. 両史料において町人地内の広小路 (火除地) は, その管理 上，「往来雨落其外之分」(町家前の下水より外側部分の人びとが往来する 場所)，つまり町内の通り一般と同等のものとして分類されている.

26）江戸の個別の広小路 - 火除地については、その利用・運用形態とあわせ て維持管理の実態も明らかにされている（前掲註 24)）。筆者は、こうした 広小路における「持場」は、本稿で論じた個別町の「持場」とは別の類型 として把握できると考えている。ただし、広小路のみを特異な存在として とりあげるのではなく、町の「持場」と類似した性格をもつ武家や寺社の 負担のあり方、「持場」の生成や変容過程をふまえた個別的な道空間の事例 分析をもとに、市中全体のなかで包括的に整理する必要があると考えてお り、この点は別稿で論ずる予定である。

27）『享保撰要類集』7 下ノ上, 「明地之部」, 第 50 件 (旧幕). 


\title{
MAINTENANCE OF STREET SPACES AND MOCHIBA (POSTS OF RESPONSIBILITY) IN EDO COMMONERS DISTRICT
}

- A case study of Minami tenma chō 2, Minami saya chō, Minami nushi chō, and Matsukawa chō $1 \cdot 2$ -

\section{Genki TAKAHASHI ${ }^{* 1}$}

\author{
${ }^{* 1}$ Research Assoc., Dept. of Architecture, School of Engineering, The University of Tokyo, Ph.D. in Eng.
}

\begin{abstract}
The shogunate was responsible for controlling and managing the various activities conducted on the streets of Edo commoners district (chōninchi). The street spaces, on the other hand, were maintained by the townsman (chōnin) who lived in the commoners district. While the town commissioner (machi-bugyo), street commissioner (michi-bugyō) and the commissioner of engineering works (fushin-bugyō) were the shogunate officers in charge of supervising the work, the commoners led the actual maintenance work. Their task of maintaining street spaces (street functions and public safety) was assumed both in terms of workload and cost by the towns along the street, and the range managed by each town could be spatially. The purpose of this paper is to illustrate Mochiba (the posts of responsibility) that were spatial divisions to the town's management of street spaces and the feature of spatial maintenance system based on a case study of Minami tenma chō 2, Minami saya chō, Minami nushi chō, and Matsukawa chō.. This paper uses the
\end{abstract} term "street spaces" to comprehensively describe the human and built environment that evolves along the street.

The first section investigates how Mochiba (posts of responsibility) was positioned in the management system of the street spaces by the shogunate (machi-bugyō, the town commissioner). It points out that the town commissioner (machi-bugyō) strongly recognized the spatial range that the town $(c h \bar{o}-j \bar{u})$ should be responsible for the maintenance and order around the 18th century. It correlated with the management system for street spaces was established by the shogunate by mandating an application process for the townsman's various management and construction activities carried out on the street in the 18th century as pointed out in my paper. Based on the above, I presented the following hypothesis. Mochiba was equivalent to the range where the prefix attached to each house and lot (ie-yashiki), and had in the cooperativeness and exclusivity of the town (chō). In other words, it was not the principle set from above by the shogunate. Although the shogunate did not clearly make Mochiba legal system, they attempted to thoroughly enforce this control by dividing the street space into Mochiba (posts of responsibility) and assigning these Mochiba to the various towns and each owner of the residence.

The following section analyzes the specific character of the Mochiba in commoners district (chonin-chi), based on a case study of Minami tenma chō 2, Minami saya chō, Minami nushi chō, and Matsukawa chō. Therefore, the section was examined from three theme: Ban (maintaining public peace and order) and the restoration of the street and sewage (maintenance of street function) that it is the most basic in maintenance work of the street spaces by the town. This discussion gave that physical environmental conditions of street spaces prescribed an individual assumption of responsibility for maintenance and management by townsman (chō-nin) and chō.

Lastly, I would like to point out that the spatial feature of Mochiba (posts of responsibility) in commoners district. Then, the paper concludes with a discussion on the responsibility of the maintaining public safety and the maintenance of street function could be separated on one street through a case study of Mochiba was newly set or expanded. 